This is the post print version of the article, which has been published in British journal of politics \& international relations . 2018, 20 (1), 158-174. http://dx.doi.org/10.1177/1369148117745682.

\title{
Parliament as an arena for politicization: The Finnish Eduskunta and crisis management
}

The This document has been downloaded from TamPubutafi The Institutional Repository of University of Tampere

\section{operations}

Tapio Raunio, Faculty of Management / Politics, 33014 University of Tampere, Finland, email: tapio.raunio@uta.fi

\begin{abstract}
The literature on parliamentary war powers has focused on the veto rights of legislatures. This case study on the Finnish Eduskunta adopts a more comprehensive approach. Based on parliamentary documents and statistics, it reconstructs parliamentary involvement in decision-making on individual crisis management operations, laws on crisis management, and 'grand strategy' documents since the mid-1990s. The findings underscore the importance of politicization, with conflicts over legislation and the Government Security and Defence Policy Reports enabling political parties and the Eduskunta to set parameters for subsequent decisions on individual operations. The politicization of crisis management facilitated stronger participation rights for the Eduskunta and created 'ownership' of troop deployments among MPs. Debates have nonetheless become less intense, with broader crossparty support for participation in crisis management and for EU-led operations in particular.
\end{abstract}

\section{Acknowledgements}

I am grateful to the editors of this Special Issue, the two external reviewers, Unto Vesa, and the participants of the workshop Parliaments and Security Policy: Control, Legitimacy and Effectiveness, 22-23 September 2016, PRIF, Frankfurt, and TCIS seminar, 6 December 2016, Dalarna University, Falun, for their constructive feedback. Ville Rantala and Taru Ruotsalainen provided valuable research assistance. 


\section{Key words}

Politicization, parliament, crisis management, security policy, political parties, Finland

\section{Word count}

6993

\section{Introduction}

During the Cold War United Nations (UN)-led peacekeeping operations were important for Finland and the other Nordic countries. The Nordic countries contributed $25 \%$ of the personnel in UN operations, with institutionalized cooperation between them in peacekeeping issues. The Nordic nations developed a reputation as peace-builders, with peacekeeping a key component of 'Nordicness' or the 'Nordic model'. Peacekeeping mattered also in terms of self-perception and national identity. As Finland was not able to participate in European integration or in security cooperation with the 'west', peacekeeping offered it an avenue for participation in international politics. Peacekeeping was widely reported in national media, emphasized in schoolbooks, and it enjoyed broad support among the political elites and the public. The first Finnish peacekeepers were dispatched to the United Nations Emergency Force (UNEF) in Suez in 1956, and since then around 45000 Finns have served abroad in peacekeeping duties. ${ }^{1}$

However, in the post-Cold War era the situation is vastly different: peacekeeping has been replaced with crisis management, the number and diversity of operations has increased significantly, UN is no longer the only actor in the scene, with particularly the European Union (EU) and also the North Atlantic Treaty Organization (NATO) carrying out missions. The Nordic countries responded by amending their peacekeeping laws so that their troops could both use force beyond self-defence and participate in missions led by NATO, EU and the Organization for Security and Cooperation in 
Europe (OSCE). Out of the Nordic countries this adaptation was arguably hardest for Finland, a militarily non-aligned country for whom good relations with Russia have understandably been a top priority. (Vesa, 2007; Stamnes, 2007; Jakobsen, 2006)

This changing security context forms the starting point of this article, which examines the role of the Eduskunta, the unicameral legislature, in national decision-making on crisis management. As outlined in the introductory article to this Special Issue (Mello and Peters, 2017), previous literature on parliaments and security policy has for the most part focused on executive-legislative relations and on tracing the impact of parliamentary involvement. Scholars have paid less attention to the debating function of parliaments in security matters and how such politicization is related to government scrutiny. In the post-Cold War era there are good reasons to expect more debate and ideological contestation about crisis management and 'wars of choice', both regarding what operations countries participate in and in what capacity (Raunio and Wagner, 2017b). Hence this article addresses the question outlined in the introductory article: 'when parliaments become involved in security policy does this foster transparency and contribute to the politicization of security policy so that security policy becomes a “normal” political issue?' (Mello and Peters, 2017)

The article emphasizes legislatures as a site for politicization of security policy, showing that partypolitical conflicts over crisis management facilitated stronger opportunity structures for parliamentary engagement in troop deployments in Finland. Analysing the parliamentary processing of all individual operations, laws on crisis management, and national 'grand strategy' documents from 1995 to 2016, it shows that there is clearly a sense of 'ownership' of crisis management among Finnish MPs, with troop deployments and the operations subject to close parliamentary scrutiny. The main causal argument of this article is thus that politicization of crisis management brings about stronger parliamentary accountability of the government. Essentially crisis management has become part of 
normal parliamentary politics, with the Eduskunta receiving information from the government and organizing committee hearings and plenary debates exactly as it does in salient domestic issues.

\section{Analytical Framework: Parliaments as Sites of Politicization, the Changing Security Context, and Ideological Conflict}

\section{Parliaments and Politicization}

Referring to a recent Special Issue on politicization of EU affairs, we 'posit that politicization can be empirically observed in (a) the growing salience of European \{crisis management] governance, involving (b) a polarisation of opinion, and (c) an expansion of actors and audiences engaged in monitoring EU affairs [crisis management]' (de Wilde et al., 2016: 4). As is shown below, these requirements were fulfilled in the case of crisis management in Finland. Parliaments and particularly plenary debates provide a fertile ground for politicization. Unlike committees that often meet behind closed doors, plenary debates are held in public, broadcast (at least online) live, with full verbatim accounts available. The presence of government ministers in the chamber facilitates media coverage, with opposition parties thus having stronger incentives to criticize the cabinet. Moreover, debates offer backbenchers, particularly those who need to signal their positions to the electorate, the chance to express their views and discomfort with the initiatives, even against the position of their own parties. While MPs may be 'whipped' into following the party line in voting, 'rebels' can still often take the floor to disagree with their party leaders (Proksch and Slapin, 2015; Bäck and Debus, 2016).

From a normative perspective debates can even be considered the most important way in which legislatures contribute to security policy. The plenary provides a public forum for debate where the security policy choices are justified and explained (Lord, 2011), especially when there are political parties offering alternatives and a healthy media covering the debates (Baum and Potter, 2015). As 
argued in the introduction to this Special Issue, 'having parliaments debate security may well lead to a politicization of security which extends partisan politics beyond the water's edge. It can put the executive under pressure to justify its policies publicly and provide room for the opposition to test the government's arguments and seek public support for its own position.' (Mello and Peters, 2017) But politicians themselves may have good reasons to favour less transparent, consensual modes of policy-making. MPs may defend meeting in camera with the need to ensure confidential exchange of information with the government, which in turn facilitates stronger parliamentary scrutiny of security policy. MPs may also believe that unity at home improves the bargaining position of the government or the morale of troops abroad. Overall, in security policy decision-makers often evoke notions of national unity and demand that the major political parties at least try to build consensus on these issues so that disunity at home does not undermine success abroad.

Importantly, parliamentary politicization can trigger stronger accountability of the government, especially if the issue divides opinion also inside cabinet parties. When faced with an assertive legislature, the government can buy its support through agreeing to procedures - such as reporting requirements or ex ante veto - that enhance oversight of the cabinet and parliamentary participation rights. Naturally the government itself may also benefit from such procedures, as ex ante parliamentary approval should facilitate support for the government in subsequent stages of policymaking. In crisis management missions this means that the legislature should be less critical during the operations when it has been consulted about the initial troop deployment - thus providing credibility to the country’s international commitments (e.g. Martin, 2000).

\section{The New Security Context and the Empowerment of the Eduskunta}

Finland certainly belongs to those countries where national unity is emphasized in security policy. During the Cold War foreign policy was very much driven by the concept of neutrality: political 
debate and contestation on security policy were rare and maintaining amicable relations with the Soviet Union was a top priority. When the Soviet Union collapsed, Finland wasted no time becoming fully engaged in European integration, joining the EU in 1995.

Many voices questioned whether a neutral country with a long border with Russia could contribute meaningfully to European security integration. Calming such doubts is probably one of the reasons why Finland has actively supported the development of the Common Security and Defence Policy (CSDP) (Jokela, 2011; Palosaari, 2011). In the Intergovernmental Conference of 1996-97 Finland and Sweden formulated an initiative according to which the EU should create a military crisis management capacity. ${ }^{2}$ The focus on crisis management was understandable: not only does Finland have a long-standing reputation for active participation in peacekeeping operations, crisis management also offered a way to make a positive contribution to CSDP when NATO membership is not an option.

Turning to the constitutional framework, the fall of the Soviet Union and EU membership acted as catalysts for constitutional change from the early 1990s onwards. Under the old constitutional regime foreign policy was the exclusive domain of the president, and hence the new constitution, which entered into force in 2000, has for the first time granted the Eduskunta genuine authority in external affairs. The government is responsible for EU policy with foreign policy leadership shared between the president and the government. (Raunio, 2012) The Foreign Affairs Committee (FAC) of the Eduskunta considers EU issues pertaining to foreign and security policy, while according to section 97 of the constitution the FAC 'shall receive from the Government, upon request and when otherwise necessary, reports of matters pertaining to foreign and security policy. ${ }^{3}$ Finally, all international obligations and commitments with legislative or budgetary implications must be approved by Eduskunta. This empowerment of the Eduskunta in foreign and security policy enjoyed broad support 
among political parties. Previous research indicates that the Eduskunta also uses actively its new-won powers, with the FAC not only insisting on government fulfilling its reporting obligations but also requesting further information from the cabinet. Ex ante mechanisms are crucial, with the FAC receiving information from the government and hearing ministers ahead of EU or international meetings. (Raunio, 2016)

The formulation of the grand strategy document, which outlines the core objectives and issues in security policy, provides an important channel for parliamentary influence in security policy. The report, titled since 1995 the Government Security and Defence Policy Report and published roughly every four years, provides an overall framework for subsequent foreign and security policy decisionmaking, including in crisis management. The government drafts the report, but the process is monitored by a parliamentary working group that brings together representatives from all Eduskunta parties, opposition included. In the Eduskunta the report is scrutinized carefully, with the Defence Committee (DEFC) submitting a statement to FAC which produces a report on the draft report. Finally, the plenary debates and approves the final report.

Amendments to national peacekeeping legislation reflect the domestic constitutional reforms, the changing security context, and specifically the development of CSDP (Tiilikainen, 2008; Palosaari, 2011). Until mid-1990s the legislation was based on two leading principles - the necessity of a UN or OSCE mandate and the impossibility of peace enforcement as Finnish soldiers were allowed to use force only for self-defence. An amendment from 1995 created the right to 'extended peacekeeping', implying the possibility for more extensive use of force. ${ }^{4}$ Five years later another amendment increased the compatibility of Finnish legislation with the EU treaties which, since 1999, have entitled the EU to carry out all types of crisis management operations. The prohibition to participate in peace enforcement was abolished, and according to the same amendment Finland can participate in 
humanitarian operations or in the protection of such operations at the request of UN organizations or agencies. ${ }^{5}$ The most recent significant change was introduced in 2006, with the title of the new law explicitly referring to 'crisis management' instead of 'peacekeeping'. The government argued that 'military crisis management' describes the EU’s tasks more accurately than 'peacekeeping' and that the reform was needed in order for Finland to participate fully in crisis management operations led by UN, EU or NATO and in EU's Battlegroups. Since 2006 Finnish troops can be assigned to all types of crisis management operations, even to missions lacking the mandate of the UN Security Council. $^{6}$

The Eduskunta was involved in decision-making about peacekeeping operations already during the Cold War. Although the decision to participate in the Suez operation in the 1950s had been subject to a parliamentary debate, the rule whereby troops could be deployed only after having heard the opinion of the FAC was established in connection with a government bill for new peacekeeping legislation that was introduced in 1964 to enable Finland's participation in UNFICYP (United Nations Forces in Cyprus). In fact, this initial empowerment of the Eduskunta provides the first example of the effects of politicization, as the Cyprus operation produced controversy in the parliament and also active public debate. Most vocal critique was expressed by the predecessor of Left Alliance, the Finnish People’s Democratic Union, but the issue was clearly salient also among the other parties. (Vesa, 2007: 526)

However, the reforms introduced in the post-Cold War era have significantly changed both the legal framework and especially the broader participation rights of the parliament. Here one must emphasize the importance of the broader constitutional changes that provide a solid backbone for parliamentary engagement in security policy and crisis management. The Eduskunta has vigorously and successfully pushed for stronger ex ante and ex post accountability mechanisms. The government is the key actor, 
negotiating about operations abroad and planning Finnish participation. However, the president, as the commander-in-chief of the defence forces, has the final say about troop deployment, but the presidents have not contested the decisions. Essentially the Eduskunta and specifically the FAC are heard before the issue is decided in the cabinet. The same applies if the tasks of the Finnish personnel are significantly changed during the operation. ${ }^{7}$ The law from 1995 introduced the possibility for 'extended peacekeeping', but also stipulated that consultation of FAC was needed in such instances. According to the law from 2000, when international operations do not fulfill the conditions of traditional UN peacekeeping operations, whether in relation to their mandate or authorization to use force, the government must produce a report ${ }^{8}$ to the plenary of the Eduskunta. The same applies if the duties of the Finnish personnel change significantly during the operation. In short, the FAC or the plenary is consulted before each operation and the Eduskunta receives regular reports on the operations, for example in the form of biannual crisis management overviews. ${ }^{9}$

To conclude, the Eduskunta is in the post-Cold War era actively involved in foreign and security policy, with the 'grand strategy' document and crisis management legislation in particular enabling the parliament to set constraints on subsequent policy choices, including participation in individual operations. Returning to the criteria of politicization, we have so far seen that instead of leaving such matters to the executive, parliamentary involvement has brought about 'an expansion of actors and audiences engaged in monitoring crisis management'. Peacekeeping or crisis management has also been definitely 'salient' in Finland, and as argued in the next sub-section, issue salience has only increased in the post-Cold War era which has also witnessed stronger 'polarisation of opinion'.

\section{Decision-making Culture: Consensus or Ideological Conflicts?}

According to previous literature party politics does matter in security policy, with 'hawks' more often found among right-leaning legislators and 'doves' on the left. In the U.S. context there is strong 
evidence of such a divide between Democrats and Republicans (e.g. Poole and Rosenthal, 1991; Milner and Tingley, 2015). Wagner et al. (2017) show how ideology impacts preferences regarding both policy and procedures. Utilizing Chapel Hill Expert Survey data, they first demonstrate that while ideological centrism produces convergence across European countries, political parties on the right with the exception of the radical right are more supportive of military missions than those on the left. Case studies of Germany, France, Spain and the United Kingdom in turn show that parties on the left tend to favour stronger parliamentary control whereas those on the right tend to prefer an unconstrained executive. The articles in the collection edited by Raunio and Wagner (2017a) indicated a clear pattern, with left-wing MPs more interested in curbing executive autonomy in security policy. Other studies also provide evidence of centre-right parties or governments being more supportive of military operations, such as joining the 'coalition of the willing' in the Iraq War or the operation in Afghanistan (e.g. Palmer et al., 2004; Rathbun, 2004; Schuster and Maier, 2006; Arena and Palmer, 2009; Clare, 2010; Mello, 2014).

In Finland, consensus on security policy has traditionally been strong. The post-Cold War foreign policy debates have focused on three inter-related questions: Russia, CSDP, and crisis management (Raunio, 2016). Importantly, there are now overall much more debates about foreign and security policy, with also clearer differences between political parties. Overall, questions related to national security and defence remain very delicate and salient. While parliamentary culture in foreign and security policy remains quite consensual, the left-right cleavage structures often the discussions, with centre-left parties emphasizing a more comprehensive or broader approach to foreign affairs, including human rights and development policy, while centre-right parties are more against cuts to defence spending and more supportive of developing closer links with NATO - ideological differences which were already visible even during the Cold War era (Joenniemi, 1978). 
Turning to crisis management, the number of Finnish troops sent abroad is low, their tasks mainly relate to the 'peacekeeping' or civilian side of the missions, and the operations are carried out far beyond national borders. Hence the operations have no immediate impact on national security. Instead, we expect to find another driver of politicization at work. Missions coordinated by the UN or EU should not see much contestation. UN-led operations have been a cornerstone of national foreign policy. Finland was behind the initiative to develop the crisis management capacity of the Union, and national debates and changes to crisis management legislation have been strongly influenced by the need to act together with the other EU member states (Palosaari, 2011). Public support for crisis management operations is also solid. For example, in Finnish National Election Study (FNES) surveys carried out at the time of the 2007, 2011 and 2015 Eduskunta elections, comfortable majorities in every party - except the Finns Party in 2011 - agreed with the statement that Finland's participation in international crisis management is a positive thing.

Operations led by NATO are likely to generate more disagreement. While Finland joined the Partnership for Peace in 1994, public opinion on actual NATO membership has remained rather stable, below $30 \%$. Only the conservative National Coalition is in favour of membership and even it does not campaign actively on the issue. The other parties basically subscribe to the official foreign policy line whereby links with NATO are maintained and developed while membership is an option that needs to be kept open. Comparing the electorates of the parties, we can observe a clear left-right divide (Table 1). Support for NATO membership is strongest in the National Coalition and the Swedish People's Party which represents the interests of the Swedish-speaking minority, while it is essentially below $30 \%$ in all the other parties, and even below $10 \%$ in the Left Alliance. In addition, a survey by the Advisory Board for Defence Information asked from 2004 to 2008 the respondents about support for NATO-led crisis management operations. It was strongest among voters of National Coalition and Swedish People’s Party and lowest among Left Alliance supporters. 


\section{TABLE 1}

There is thus more room for party-political differences, and in line with the third criterion of politicization, there is also increasing 'polarisation of opinion' regarding security policy and crisis management. As the concept of non-alignment and contributing to UN-led peacekeeping has framed much of the security policy debate, changes to that status quo are likely to be particularly contested. Hence we expect that the further away the laws and operations move from traditional peacekeeping and UN mandates, the higher the level of politicization and intensity of debate (H1). And given that left-wing parties and their electorates are more sceptical of developing links with NATO and of use of force in general, we expect that the debates are influenced by the left-right cleavage, with the leftwing parties more critical of changes to peacekeeping legislation and of NATO-led operations and more supportive of parliamentary participation rights (H2).

\section{Empirical Analysis}

The empirical section is divided into two parts. The first examines crisis management legislation and the Government Security and Defence Policy Reports, with the second analysing individual crisis management operations. The parliamentary processing of each law and operation is reconstructed with the help of government's draft bills and parliamentary documents (committee minutes and statements, plenary debates and votes). ${ }^{10}$

FAC is the main forum for scrutiny of crisis management, and of foreign and security policy in general. The Defence Committee, on the other hand, mainly focuses on defence forces. Committees meet behind closed doors and the information contained in their public minutes is restricted to listing the agenda items, which MPs and expert witnesses were present and spoke, and potential votes and 
dissenting opinions. Any speeches or questions, and any replies from government representatives are not minuted. Unfortunately roll-call votes are not used that often, and hence Tables 2 and 3 just include the number of plenary votes.

While dissenting opinions enable us to tap into the level of contestation in committees, the number of plenary speeches and votes and a close reading of the debates are employed to examine the salience of the issues, party positions and the diversity of opinion inside political parties. After the minister has opened the plenary discussion, party group spokespersons take their turns after which individual MPs can speak. A final indicator is expert hearings in FAC and DEFC. The rationale for incorporating expert consultation is three-fold. First, while the responsible ministry can hear external experts, independent hearings organized by the Eduskunta enhance scrutiny by reducing dependence on information provided by the government. Second, particularly when considering that most operations take place in unstable and distant regions, testimony from non-governmental actors such as interest groups or academics can diversify the range of information available to the committee. And third, interest group access to committees correlates with issue salience (Chaqués-Bonafont and Muñoz Márquez, 2016), and hence the number and range of experts indicates how important the various crisis management matters are. When combined, committee and plenary data should thus provide a reliable picture of both party positions and the politicization of crisis management in the Eduskunta.

\section{Crisis management legislation and 'grand strategy' documents}

Table 2 contains information on the parliamentary processing of the three main changes to legislation

- from 1995, 2000 and 2006. ${ }^{11}$ There was clear consistency in party positions irrespective of government-opposition dynamics. The National Coalition and the Swedish People's Party were the strongest supporters of the reforms, with Social Democrats also backing the proposals. The most vehement dissent was expressed by the Left Alliance, the most left-wing party in the Eduskunta. Even 
when in government from 1995 to 2003, it criticized the moves towards peace enforcement and crisis management and the relaxation of the requirement for UN or OCSE mandate. The Left Alliance in several instances also argued against the intrusion of NATO into peacekeeping operations.

\section{TABLE 2}

More interesting is the position of the Centre Party. In opposition from 1995 to 2003, it attacked the reforms and defended traditional forms of peacekeeping, reminding that the main task of the defence forces is territorial defence. The party line changed when it became the leading cabinet party after the 2003 elections, with Prime Minister Matti Vanhanen justifying the 2006 reforms with the need to adapt to the EU's expanding military dimension. Also the Christian Democrats, the Finns Party, and occasionally the Greens were against the abolishment of the requirement for a UN mandate, with the Greens in particular advocating a pro-active role for Finland in civilian crisis management. The opposition and internal diversity of the Left Alliance and the Centre show also in the number of dissenting committee opinions and plenary speeches. Those more critical of proposed changes were also the most vocal demanding stronger participation rights for the Eduskunta.

The reform from 1995 provides an example of the Eduskunta actually influencing government's policy (see also Palosaari, 2011: 101-112). Legislative change was linked to NATO asking if Finland could participate in its Implementation Force (IFOR) in Bosnia. To allow Finland's participation, the draft bill recommended that missions by other organisations than UN would be permissible if they had UN authorization. The government also outlined that operations with an extended authorization to use force would be allowed. The discussions in the committees and in the plenary were quite heated, and in the end Eduskunta and its FAC amended the proposal by specifically excluding peace enforcement operations. 
Six government reports on security and defence policy have been published since the mid-1990s - in 1995, 1997, 2001, 2004, 2009 and 2012. ${ }^{12}$ In addition, a specific report on improving crisis management and humanitarian aid capabilities was published in 1996. Overall, the parliamentary debates on the reports in 1995, 1996 and 1997 focused very much on non-alignment and changes to peacekeeping legislation, with particularly the Centre Party and the Christian Democrats against changes to the status quo. The Left Alliance also emphasized traditional forms of peacekeeping. Other parties were in favour of relaxing the requirements for participation in international operations. The reports and related parliamentary debates since the turn of the millennium have paid less attention to crisis management, dealing instead mainly with credibility of territorial defence, non-alignment, NATO, and the Ottawa Mine Ban Treaty. The exception was the 2004 report when the development of EU's crisis management and rapid reaction forces were on the agenda. In 2009 the Left Alliance wanted civilian crisis management to be prioritized ahead of military crisis management. In the dispatch debate of the 2016 report, the term 'crisis management' appeared only ten times in the 108 speeches, with most of the speakers just mentioning that participation in crisis management is important.

\section{Individual operations}

Included in the data set are all operations that Finland has joined since 1995 . However, Table 3 contains only those operations that were discussed in the Eduskunta. ${ }^{13}$ For each operation, the analysis focuses on the decision to participate in the mission but also debates held in connection with subsequent government reports on the missions are examined. While individual operations and crisis management as a whole come up in various plenary debates and oral or written questions, the initial deployment debates are likely to be the most important and also ones where the debate is about the operation itself. 


\section{TABLE 3}

On average, individual operations saw less debate and politicization than crisis management laws and to a certain extent also the 'grand strategy' documents. Turning to expert hearings, the number of individuals heard by FAC and DEFC is roughly the same between laws and operations. However, when scrutinizing individual operations committees do not hear representatives of non-governmental organisations, which suggests the higher salience of crisis management laws and the 'grand strategy' documents. Of the operations, the NATO-led missions in particular sparked lively debates characterized by concerns about the nature of the operations, the safety of Finnish personnel, and the move away from UN mandate towards peace enforcement. As shown by the number of dissenting opinions, experts heard, speeches, and votes, this applied especially to ISAF, with considerable unease among MPs about the whole operation and the situation in Afghanistan (Salonius-Pasternak, 2010). Participation in KFOR in 1999 also inspired intensive debates, not least on account of NATO bombing Yugoslavia ahead of the operation (Forsberg, 2000). Operations carried out by UN or EU enjoyed in general cross-party consensus, although some of them, such as UNIFIL or EUNAVFOR Atalanta, did see more contestation.

In terms of party politics, the National Coalition, the Swedish People's Party, the Social Democrats, and after initial hesitance also the Centre Party, were overall supportive of the operations, including those led by NATO. Strongest support was shown throughout by the National Coalition. The Greens were also by and large in favour, but stressed the importance of civilian crisis management, a concern shared by several other parties, not least the Christian Democrats. The Finns Party has argued in favour of credible national defence, and much of its criticism of the operations was based on their costs, questioning whether expensive operations are needed. Again the most vocal criticism came 
from the Left Alliance. It is the only party represented in the Eduskunta that has consistently criticized those operations moving away from UN mandates and traditional peacekeeping. Those more critical of the operations, primarily but not exclusively from the left-wing parties, were also more active in defending parliamentary rights, particularly in terms of the Eduskunta receiving sufficient information from the government. While $\mathrm{H} 1$ is thus clearly confirmed by the analysis, $\mathrm{H} 2$ about the left-right cleavage receives more mixed support. The high number of speeches also indicates lack of unity within parties, and many of them, including the Left Alliance, are split over security and defence questions.

\section{Conclusion}

The causal argument in this article is that the legislature offers a site for politicization of security policy which in turn can trigger stronger parliamentary involvement in crisis management. Returning thus to the definition of politicization employed in this article, there was definitely 'growing salience' of crisis management in the 1990s, not least due to the changing security context and the associated move away from UN-authorized operations that had been a key dimension of national security policy. There was also an 'expansion of actors and audiences' engaged in monitoring crisis management both through parliamentary involvement where the debates were not limited to a small circle of MPs and in the society at large, with relevant stakeholders contributing to the discussions that also received considerable media coverage. This period of politicization was genuinely significant, for it resulted in stronger participation rights for the Eduskunta and created a sense of 'ownership' among MPs towards crisis management. Moreover, it must be emphasized that already the initial involvement of the Eduskunta from the 1960s was driven by politicization. The timeline in Table 4 summarizes this trend towards stronger parliamentary engagement.

\section{TABLE 4}


Instead of 'polarisation of opinion', it is perhaps better to talk about overall politicization and diversity of opinion. To be sure, there was broad cross-party support for consolidating the role of the Eduskunta in crisis management decision-making as part of the overall parliamentarization of the political system, security policy included. However, the government bills and reports, particularly regarding peacekeeping legislation, sparked intensive debates in the committees and the plenary, with a section of the MPs of cabinet parties joining the opposition in criticizing the proposed changes and demanding stronger participation rights for the Eduskunta. Crisis management has nonetheless arguably become less politicized, with broader backing for stronger international engagement in crisis management and for EU-led operations in particular. Joining NATO-led missions is still a thorny question for a section of MPs, especially in the Left Alliance, with the civilian aspect of missions in turn not contested in the legislature. Overall, primarily left-leaning MPs continue to stress more traditional peacekeeping values, including UN mandates, and the civilian side of the missions. Those more critical of the operations have also been on average more assertive in defending the rights of the Eduskunta and in asking for more detailed information and better justifications from the government.

Highly politicized debates have thus given way to close ex ante and ex post scrutiny of the government, with crisis management thus subject to same parliamentary procedures as salient domestic issues. Particularly important are the plenary debates, with MPs not afraid to challenge the government or to voice their dissent publicly. At the same time we must not exaggerate the influence of the Eduskunta, with particularly decision-making on individual operations very much in the hands of the government (see also Koivula and Sipilä, 2011). The Eduskunta has at no point vetoed or tried to veto participation, but it is nonetheless clear that the legislature constrains the executive. Not only does the government consult the Eduskunta before each operation, the FAC also receives information 
during the operations and ex post, for example in the form of biannual crisis management overviews. The findings are thus in line with Martin (2000: 201), who argued that the executive may try to evade legislative constraints in one-off situations, whereas parliamentary engagement will be more institutionalized in stable and repeated forms of international cooperation. ${ }^{14}$

\section{References}

Arena P and Palmer G (2009) Politics or the Economy? Domestic Correlates of Dispute Involvement in Developed Democracies. International Studies Quarterly 53(4): 955-975.

Baum MA and Potter PBK (2015) War and Democratic Constraint: How the Public Influences Foreign Policy. Princeton: Princeton University Press.

Bäck H and Dabus M (2016) Political Parties, Parliaments and Legislative Speechmaking. Basingstoke: Palgrave Macmillan.

Chaqués-Bonafont L and Muñoz Márquez LM (2016) Explaining interest group access to parliamentary committees. West European Politics 39(6): 1276-1298.

Clare J (2010) Ideological Fractionalization and the International Conflict Behavior of Parliamentary Democracies. International Studies Quarterly 54(4): 965-987.

De Wilde P, Leupold A and Schmidtke H (2016) Introduction: the differentiated politicisation of European governance. West European Politics 39(1): 3-22. 
Dieterich S, Hummel H and Marschall S (2010) Parliamentary War Powers: A Survey of 25 European Parliaments. Geneva Centre for the Democratic Control of Armed Forces, Occasional Paper No. 21.

Forsberg T (2000) Finland and the Kosovo Crisis: At the Crossroads of Europeanism and Neutrality. Northern Dimensions 2000: 41-49.

Häkkinen T (2015) Parlamentaarinen päätöksenteko ja asevoimien käyttö: Tarkastelussa Britannian ja Suomen poliittisia keskusteluja asevoimien käytöstä 1990- ja 2000-luvun konteksteissa. Politiikka 57(1): 1-17.

Jakobsen PV (2006) Nordic Approaches to Peace Operations: A New Model in the Making? Abingdon: Routledge.

Joenniemi, P (1978) Political Parties and Foreign Policy in Finland. Cooperation and Conflict 13(1): 43-60.

Jokela J (2011) Europeanization and Foreign Policy: State Identity in Finland and Britain. Abingdon: Routledge.

Koivula T and Sipilä J (2011) Missing in action? EU crisis management and the link to domestic political debate. Cooperation and Conflict 46(4): 521-542.

Lord C (2011) The political theory and practice of parliamentary participation in the Common Security and Defence Policy. Journal of European Public Policy 18(8): 1133-1150. 
Martin LL (2000) Democratic Commitments: Legislatures and International Cooperation. Princeton: Princeton University Press.

Mello PA (2014) Democratic Participation in Armed Conflict: Military Involvement in Kosovo, Afghanistan and Iraq. Basingstoke: Palgrave Macmillan.

Mello PA and Peters D (2017) Parliaments in Security Policy: Involvement, Politicisation, and Influence.

Milner HV and Tingley D (2015) Sailing the Water's Edge: The Domestic Politics of American Foreign Policy. Princeton: Princeton University Press.

Palmer G, London T and Regan P (2004) What's Stopping You? The Sources of Political Constraints on International Conflict Behavior in Parliamentary Democracies. International Interactions 30(1): $1-24$.

Palosaari T (2011) The Art of Adaptation: A Study on the Europeanization of Finland's Foreign and Security Policy. Tampere: TAPRI Studies in Peace and Conflict Research No. 96.

Poole KT and Rosenthal H (1991) Patterns of Congressional Voting. American Journal of Political Science 35(1): 228-278.

Proksch S-O and Slapin JB (2015) The Politics of Parliamentary Debate: Parties, Rebels and Representation. Cambridge: Cambridge University Press. 
Rathbun BC (2004) Partisan Interventions: European Party Politics and Peace Enforcement in the Balkans. Ithaca, NY: Cornell University Press.

Raunio T (2012) Semi-presidentialism and European integration: lessons from Finland for constitutional design. Journal of European Public Policy 19(4): 567-584.

Raunio T (2016) Refusing to be Sidelined: The Engagement of the Finnish Eduskunta in Foreign Affairs. Scandinavian Political Studies 39(4): 312-332.

Raunio T and Wagner W (eds) (2017a) Challenging Executive Dominance: Legislatures and Foreign Affairs. West European Politics 40(1): 1-19.

Raunio T and Wagner W (2017b) Towards parliamentarization of foreign and security policy? West European Politics 40(1): 1-19.

Salonius-Pasternak C (2010) Kriisinhallinnan Rajamailla: Kansanedustajat varauksellisia Afganistanin operaation nykytilanteesta. Helsinki: Finnish Institute of International Affairs Briefing Paper 64.

Schuster J and Maier H (2006) The Rift: Explaining Europe's Divergent Iraq Policies in the Run-up of the American-Led War on Iraq. Foreign Policy Analysis 2(3): 223-244.

Stamnes E (ed.) (2007) Peace Support Operations - Nordic Perspective. International Peacekeeping $14: 4$ 
Tiilikainen T (2008) Toward an Active Participation in Foreign Policy - The Role of the Finnish Parliament in International Conflict Prevention and Crisis Management. In: O’Brien M, Stapenhurst R and Johnston N (eds) Parliaments as Peacebuilders in Conflict-Afflicted Countries. Washington D.C.: The World Bank, pp. 213-223.

Vesa U (2007) Continuity and Change in the Finnish Debate on Peacekeeping. International Peacekeeping 14(4): 524-537.

Wagner W, Herranz-Surrallés A, Kaarbo J and Ostermann F (2017) The party politics of legislativeexecutive relations in security and defense policy. West European Politics 40(1): 20-41. 
Table 1. Support for NATO membership among voters of political parties.

\begin{tabular}{|l|c|c|c|c|}
\hline & 2003 & 2007 & 2011 & 2015 \\
\hline Social Democratic Party (SDP) & 19,1 & 18,8 & 18 & 15,7 \\
\hline Centre Party (KESK) & 11,1 & 21,1 & 7,8 & 27,7 \\
\hline National Coalition (KOK) & 35,3 & 61,6 & 48,6 & 66 \\
\hline Swedish People's Party (RKP) & & 36,1 & 31,6 & 87,5 \\
\hline Christian Democrats (KD) & 2,7 & 19,2 & 22,2 & 25 \\
\hline Green League (VIHR) & 10,2 & 20,5 & 7,5 & 19,7 \\
\hline Left Alliance (VAS) & 7,2 & 7,5 & 7,8 & 9,5 \\
\hline The Finns Party (PS) & 12,5 & 16 & 14,8 & 36,6 \\
\hline
\end{tabular}

Source: Finnish National Election Study (FNES). 
Table 4. Timeline of parliamentary involvement in crisis management in Finland.

\begin{tabular}{|c|c|c|}
\hline The Cold War period & $\begin{array}{l}\text { Finland contributes actively to } \\
\text { UN operations, with } \\
\text { peacekeeping a politically } \\
\text { important issue. }\end{array}$ & $\begin{array}{l}\text { Following contestation related to } \\
\text { participation in UNFICYP, the } \\
\text { Eduskunta becomes involved in } \\
\text { decision-making about peacekeeping, } \\
\text { but foreign and security policy was the } \\
\text { exclusive domain of the president. }\end{array}$ \\
\hline The 1990s & $\begin{array}{l}\text { Changes in the security context } \\
\text { resulting in amended national } \\
\text { peacekeeping legislation (1995) }\end{array}$ & $\begin{array}{l}\text { Constitutional change empowers the } \\
\text { Eduskunta which also gains stronger } \\
\text { rights in troop deployments. Stronger } \\
\text { parliamentary participation rights are } \\
\text { facilitated by politicized debates about } \\
\text { legislative changes and Finland's } \\
\text { participation in individual operations. }\end{array}$ \\
\hline Early 2000s & $\begin{array}{l}\text { Further changes in legislation } \\
\text { (2000, 2006) towards crisis } \\
\text { management and away from } \\
\text { UN mandate }\end{array}$ & $\begin{array}{l}\text { Further consolidation of the legal } \\
\text { rights of the Eduskunta, with } \\
\text { particularly NATO-led missions } \\
\text { dividing opinions in the parliament. }\end{array}$ \\
\hline 2006- & $\begin{array}{l}\text { The legal rights and procedures } \\
\text { for parliamentary scrutiny of } \\
\text { crisis management are well } \\
\text { established. }\end{array}$ & $\begin{array}{l}\text { Crisis management subject to regular } \\
\text { scrutiny in the legislature. Broader } \\
\text { cross-party consensus about the rules } \\
\text { and the operations. }\end{array}$ \\
\hline
\end{tabular}


Table 2. Parliamentary processing of crisis management laws.

\begin{tabular}{|c|c|c|c|c|c|c|c|}
\hline $\begin{array}{c}\text { Government } \\
\text { proposal }\end{array}$ & $\begin{array}{l}\text { DEFC } \\
\text { dissenting } \\
\text { opinions }\end{array}$ & Experts & $\begin{array}{c}\text { FAC } \\
\text { dissenting } \\
\text { opinions }\end{array}$ & Experts & Plenary speeches* & $\begin{array}{l}\text { Plenary } \\
\text { votes }\end{array}$ & Notes on debate and party positions \\
\hline HE 185/1995 & $\begin{array}{c}7 \text { (4 KESK, } 2 \\
\text { VAS, } 1 \text { VIHR) }\end{array}$ & 15 & 4 (4 KESK) & 13 & $\begin{array}{c}139 \text { (46 KESK, } 33 \\
\text { SDP, } 17 \text { KOK, } 13 \\
\text { KD, } 8 \text { VIHR, } 8 \text { VAS, } \\
7 \text { RKP, } 7 \text { others) }\end{array}$ & 3 & $\begin{array}{l}\begin{array}{l}\text { Debate dominated by concerns about move towards peace } \\
\text { enforcement. }\end{array} \\
\text { VAS: critical of potential participation in NATO-led operation in } \\
\text { Bosnia. } \\
\text { KESK: problematic for non-aligned country to participate in } \\
\text { other than EU or OCSE operations. }\end{array}$ \\
\hline HE 20/2000 & $\begin{array}{c}2 \text { (1 VAS, } 1 \\
\text { VIHR) }\end{array}$ & 10 & $\begin{array}{l}4 \text { (2 KESK, } 1 \\
\text { VAS, } 1 \text { KD) }\end{array}$ & 13 & $\begin{array}{c}67 \text { (25 KESK, } 13 \\
\text { VAS, } 13 \text { KOK, } 7 \\
\text { SDP, } 4 \text { VIHR, } 4 \text { KD, } \\
1 \text { RKP }\end{array}$ & 3 & $\begin{array}{l}\text { Debate focused on peace enforcement. } \\
\text { KESK: against peace enforcement and the inclusion of 'crisis } \\
\text { management' in the text. The law should emphasize that the } \\
\text { priority of the army is national defence. } \\
\text { VAS: part of MPs against the proposal. } \\
\text { VIHR: wants to develop civilian crisis management. }\end{array}$ \\
\hline HE 5/2006 & $\begin{array}{c}2 \text { (1 VAS, } 1 \\
\text { KD) }\end{array}$ & 5 & $\begin{array}{c}2 \text { (1 VIHR, } 1 \\
\text { VAS) }\end{array}$ & 4 & $\begin{array}{c}172 \text { (45 VAS, } 35 \\
\text { KOK, } 30 \text { SDP, } 24 \\
\text { VIHR, } 17 \text { KESK, } 14 \\
\text { KD, } 5 \text { PS, } 2 \text { RKP) }\end{array}$ & 4. & $\begin{array}{l}\text { Debate centred around the necessity of a UN mandate. } \\
\text { PS: against the proposal. } \\
\text { VAS: internally divided, emphasizing the importance of UN } \\
\text { mandate and how superpowers are now taking over crisis } \\
\text { management operations. } \\
\text { VAS, KD, VIHR and PS against the possibility to enter into } \\
\text { operations without a UN or OCSE mandate. } \\
\text { VIHR, VAS and KD want Finland to be especially active in } \\
\text { civilian crisis management. }\end{array}$ \\
\hline
\end{tabular}

* Excluding the opening statements from the minister and the committee chair. 
Table 3. Parliamentary processing of individual operations.

\begin{tabular}{|c|c|c|c|c|c|c|c|}
\hline $\begin{array}{l}\text { Operation and the } \\
\text { document }\end{array}$ & $\begin{array}{c}\text { DEFC } \\
\text { dissenting } \\
\text { opinions }\end{array}$ & Experts & $\begin{array}{l}\text { FAC } \\
\text { dissenting } \\
\text { opinions }\end{array}$ & Experts & Plenary speeches & $\begin{array}{l}\text { Plenary } \\
\text { votes }\end{array}$ & Notes on debate and party positions \\
\hline \multicolumn{8}{|l|}{ UN } \\
\hline $\begin{array}{l}\text { UNIFIL(1982-2001, 2006- } \\
\text { VNS } 6 / 2006\end{array}$ & $1(\mathrm{KD})$ & 7 & & 8 & $\begin{array}{l}135 \text { (33 KOK, } 23 \text { KESK, } 20 \text { VAS, } 19 \\
\text { SDP, } 18 \text { KD, } 15 \text { VIHR, } 6 \text { PS, } 1 \text { RKP) }\end{array}$ & 1 & $\begin{array}{l}\text { Death of a Finnish soldier prominent in } \\
\text { the debate. } \\
\text { Cross-party consensus behind the } \\
\text { operation, but VAS most critical, stressing } \\
\text { the importance of a UN mandate. VIHR } \\
\text { underlining the role of civilian crisis } \\
\text { management. }\end{array}$ \\
\hline UTP 16/2011 & & 4 & & 11 & & & \\
\hline HE 56/2012 & & & & 4 & 6 (4 PS, 2 KOK) & & Cross-party consensus. \\
\hline UTP 3/2013 & 2 (PS) & 6 & & 17 & & & \\
\hline $\begin{array}{l}\text { MINURCAT (2007-2010) } \\
\text { VNS 2/2009 }\end{array}$ & & 4 & & 5 & $\begin{array}{c}63 \text { (18 KESK, } 13 \text { VAS, } 10 \text { SDP, } 10 \\
\text { VIHR, } 9 \text { KOK, } 2 \text { KD, } 1 \text { PS) }\end{array}$ & & Cross-party consensus. \\
\hline \multicolumn{8}{|l|}{$\mathbf{E U}$} \\
\hline $\begin{array}{l}\text { EUFOR Concordia (2003) } \\
\text { VNS 3/2003 }\end{array}$ & & & & 2 & $\begin{array}{c}14 \text { (4 VAS, } 3 \text { KOK, } 3 \text { KESK, } 2 \\
\text { VIHR, } 1 \text { SDP, } 1 \text { KD) }\end{array}$ & & $\begin{array}{l}\text { VAS inquires about the link between the } \\
\text { operation and the UN Security Council. } \\
\text { KOK and KESK support changes to } \\
\text { legislation to make participation in EU } \\
\text { operations easier. }\end{array}$ \\
\hline $\begin{array}{l}\text { EUFOR Althea (2004-) } \\
\text { VNS 5/2004 }\end{array}$ & & 7 & & 5 & $\begin{array}{c}16 \text { (5 KESK, } 4 \text { VAS, } 3 \text { KOK, } 3 \\
\text { VIHR, } 1 \text { KD) }\end{array}$ & & \\
\hline $\begin{array}{l}\text { EUNAVFOR Atalanta } \\
\text { (2008-) } \\
\text { VNS 5/2010 }\end{array}$ & & 7 & & 6 & $\begin{array}{l}82 \text { (20 KOK, } 16 \text { KESK, } 16 \text { SDP, } 9 \\
\text { PS, } 8 \text { VIHR, } 6 \text { VAS, } 5 \text { KD, } 2 \text { RKP) }\end{array}$ & 1 & $\begin{array}{l}\text { VAS in favour if the motive for } \\
\text { participation is humanitarian aid. PS } \\
\text { against the operation. SDP supports, but is } \\
\text { internally divided. }\end{array}$ \\
\hline UTP 1/2013 & & & 2 (PS) & 3 & & & \\
\hline$\frac{\text { EUFOR Tchad/RCA }}{(2008-2009)}$ & & 5 & 2 (VAS) & 19 & $\begin{array}{c}37 \text { (9 KOK, } 7 \text { SDP, } 7 \text { KESK, } 4 \text { VAS, } \\
4 \text { VIHR, } 3 \text { KD, } 2 \text { PS, } 1 \text { RKP) }\end{array}$ & & $\begin{array}{l}\text { Cross-party consensus about participation } \\
\text { in operations outside Europe. KESK, VAS }\end{array}$ \\
\hline
\end{tabular}




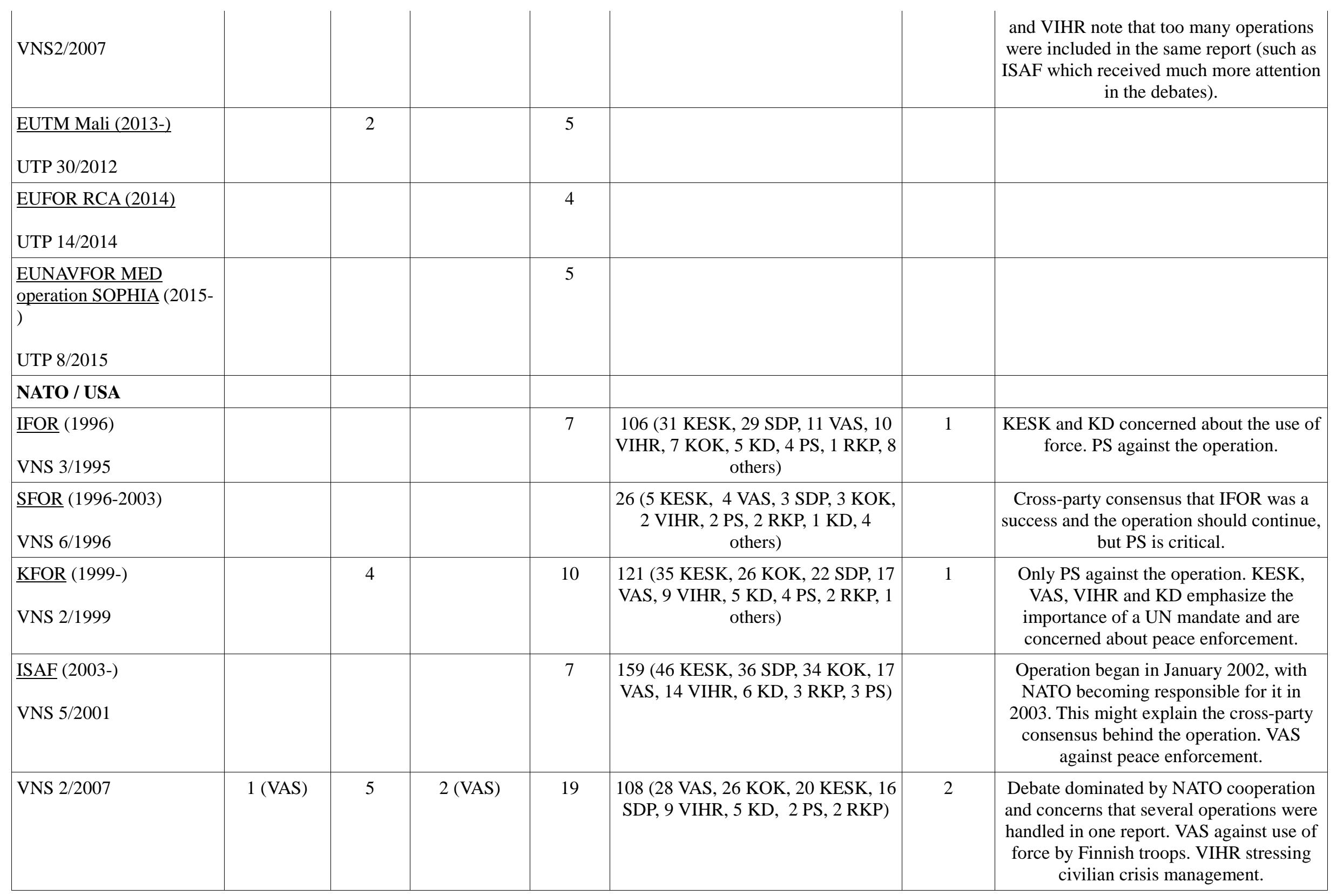




\begin{tabular}{|c|c|c|c|c|c|c|c|}
\hline VNS 8/2008 & 1 (VAS) & 6 & 2 (VAS) & 13 & $\begin{array}{l}84 \text { (25 VAS, } 16 \text { KESK, } 16 \text { KOK, } 10 \\
\text { VIHR, } 10 \text { SDP, } 3 \text { PS, } 3 \text { KD, } 1 \text { RKP) }\end{array}$ & 1 & VAS against the operation. \\
\hline $\begin{array}{l}\text { Operation Inherent } \\
\text { Resolve (2014-) } \\
\text { VNS 10/2014p }\end{array}$ & 1 (others) & 13 & & 13 & $\begin{array}{c}71 \text { (17 PS, } 11 \text { KOK, } 9 \text { others, } 8 \text { SDP, } \\
8 \text { KESK, } 6 \text { VIHR, } 5 \text { VAS, } 4 \text { KD, } 3 \\
\text { RKP) }\end{array}$ & 1 & $\begin{array}{c}\text { Cross-party consensus, with the exception } \\
\text { of two MPs that had been expelled from } \\
\text { the VAS group. Overall concerns about the } \\
\text { safety of Finnish troops. }\end{array}$ \\
\hline VNS 2/2016 & & 5 & & 10 & $\begin{array}{c}77 \text { (17 KESK, } 14 \text { PS, } 13 \text { SDP, } 13 \\
\text { KOK, } 8 \text { VAS, } 6 \text { KD, } 4 \text { VIHR, } 2 \\
\text { RKP) }\end{array}$ & & $\begin{array}{c}\text { Exceptionally strong cross-party } \\
\text { consensus. KD and VIHR advocate more } \\
\text { civilian crisis management. }\end{array}$ \\
\hline $\begin{array}{l}\text { Resolute Support (2015-) } \\
\text { VNS 8/2014 }\end{array}$ & 1 (others) & 8 & & 12 & $\begin{array}{c}56 \text { (12 KOK, } 11 \text { PS, } 10 \text { KESK, } 7 \\
\text { SDP, } 5 \text { others, } 3 \text { VAS, } 3 \text { VIHR, } 3 \\
\text { RKP, } 2 \text { KD) }\end{array}$ & 1 & VAS and VIHR emphasize UN mandate. \\
\hline
\end{tabular}


1 Puolustusministeriö, Suomalainen rauhanturvaaminen 60 vuotta, $\quad$ 5.2.2016 (http://www.defmin.fi/ajankohtaista/tiedotteet/suomalainen_rauhanturvaaminen_60_vuotta.7658.ne ws). The number of crisis management personnel, excluding rotation personnel and personnel in training, must not exceed 2000. In recent years the number of personnel has dropped and stabilized at around 400-500, largely because the operations have become more expensive. See http://www.findikaattori.fi/en/100.

${ }^{2}$ See for example 'The IGC and the Security and Defence Dimension: Towards an enhanced EU Role in Crisis Management’, Memorandum from Finland and Sweden, 25 April 1996.

3 The Constitution of Finland, 11 June, 1999 (http://www.finlex.fi/en/laki/kaannokset/1999/en19990731.pdf).

4 Laki Suomen osallistumisesta Yhdistyneiden kansakuntien ja Euroopan turvallisuus- ja yhteistyöjärjestön päätökseen perustuvaan rauhanturvaamistoimintaan (1565/95).

${ }^{5}$ Rauhanturvaamislaki (750/2000).

${ }^{6}$ Laki sotilaallisesta kriisinhallinnasta (211/2006) / The Act on Military Crisis Management (211/2006) (http://www.finlex.fi/fi/laki/kaannokset/2006/en20060211.pdf).

${ }^{7}$ Whether this obligation to consult the Eduskunta amounts to a veto is not exactly clear. Dieterich et al. (2010: 20) argue that 'consultation of the Foreign Affairs Committee or the plenary corresponds to the right of approval of the government's proposal. Thus, without the consent of parliament Finnish forces would not be sent abroad.' The FAC or the plenary have so far not rejected the government's proposals for participation.

${ }^{8}$ Valtioneuvoston selonteko, in Tables 2 and 3 marked with the abbreviation VNS.

${ }^{9}$ An amendment from 2015 streamlined the procedures through delegating more powers to the government and the Ministry of Defence, especially regarding minor personnel changes to the 
operations. The Left Alliance was the only party against the reform. See Laki sotilaallisesta kriisinhallinnasta annetun lain muuttamisesta (576/2015).

${ }^{10}$ Excluding the initial government document (VNS, UTP or HE), Tables 2 and 3 do not for reasons of space detail the identification codes of the subsequent DEFC or FAC documents nor the breakdown of experts into governmental and non-governmental sources. These full statistics are available from the author on request.

${ }^{11}$ All three proposals were also handled by the Constitutional Law Committee. The 2006 reform was initially introduced in the Eduskunta as HE 110/2005 when DEFC heard 26 experts.

_ja_puolustuspoliittiset_selonteot.

${ }^{13}$ The Eduskunta did not process operations where the contribution of Finland was very limited: UNTAES (1996-1998), UNMOP (1996-2002), UNMIK (1999), UNMEE (2000-), UNMIL (2003-), UNMISS (2005), MINUSMA (2013-), EUFOR RD Congo (2006) and EUTM Somalia (2010-).

${ }^{14}$ Problems may arise when it is legally unclear whether the government needs to hear the Eduskunta. An example was Finland's participation in NATO-led Icelandic Air Policing. Legally there seemed no obligation to consult the Eduskunta, but in the end the government decided to hear the views of the parliament. (Häkkinen, 2015) 